\title{
Genetic Diversity and Characterization of Sweet Lemon (Citrus limetta) Fruits
}

\author{
Francielly R. Gomes ${ }^{1}$, Cláudia D. M. Rodrigues ${ }^{1}$, Angelita L. S. L. Ragagnin ${ }^{1}$, Bruna S. Gomes ${ }^{1}$, \\ Gabriel S. Costa ${ }^{1}$, Isabelly da S. Gonçalves ${ }^{1}$, João P. S. M. Guimarães ${ }^{1}$, Kamila M. Silveira ${ }^{1}$, Moab A. Barbosa ${ }^{1}$, \\ Pedro H. M. Souza ${ }^{1}$, Ricardo C. Ribeiro ${ }^{1}$, Victória A. Monteiro ${ }^{1}$, Américo N. da Silveira Neto ${ }^{1}$, \\ Simério C. S. Cruz ${ }^{1} \&$ Danielle F. P. da Silva ${ }^{1}$ \\ ${ }^{1}$ Universidade Federal de Jataí, Jataí, Goiás, Brazil \\ Correspondence: Francielly R. Gomes, Universidade Federal de Jataí, Br 364, Km 192, 75801-615, Goiás, Brazil. \\ E-mail: fram_rodgomes@hotmail.com
}

$\begin{array}{lcc}\text { Received: May 8, } 2020 & \text { Accepted: June 29, } 2020 & \text { Online Published: July 15, } 2020 \\ \text { doi:10.5539/jas.v12n8p181 } & \text { URL: https://doi.org/10.5539/jas.v12n8p181 }\end{array}$

The research is financed by CAPES and CNPq.

\begin{abstract}
Citrus fruit tree has great importance in Brazil. Despite having many commercial cultivars, the lemon crop in Brazil is basically from "Tahiti" cultivar and there is a lack of studies about the characterization and assay of genetic diversity of sweet lemon (Citrus limetta) fruits. Therefore, this work aimed to characterize and evaluate the genetic diversity from nine stock plants produced in Porto Nacional-TO. Fruits in fully physiologic ripening were harvested and evaluated for weight, length, diameter, juice yield, soluble solids content, and color of peel and pulp. The experimental design was completely randomized with 9 treatments (stock plants) and five replications. For the characterization, the data were subjected to Tukey's test and similarity measure and clustering of the stock plants were performed by Tocher's method and UPGMA dendrogram. Weight, length, and diameter of all stock plants have not differed from each other. The coordinate $b^{*}$ indicated that stock plant 1 had fruits with peel and pulp clear when compared to the yellow color of the other stock plants. There was genetic diversity between the assessed stock plants and three groups were created, which stock plant 1 and 2 were the most divergent and compose group 3, according to Tocher's method. The features contributed similarly to total variation.
\end{abstract}

Keywords: sweet lemon, fruit quality, correlation, clustering

\section{Introduction}

The annual production of citrus fruits in the entire world its approximately 132 million tons, which orange, mandarin, grapefruit and lemon correspond to $98 \%$ of the production and from this amount, is produced 13.7 million tons of lemon fruit per year (Sarker, Barman, M. M. Islam, M. R. Islam, \& Chakma, 2017; Eryildiz, Lukitawesa, \& Taherzadeh, 2020). Brazil is the world's largest producer of citrus fruits, especially orange, which occupies the first position in the exportation of frozen concentrated orange juice and has exported 870,311 tons of juice in season crop 2018/2019 (Silva, Agra, Aleixo, Nóbrega, \& Dantas, 2011; Brazilian Association of Citrus Exporters [ABECITRUS], 2020).

Citrus fruits can be destined to fresh consumption or processed for the manufacturing of juices, jelly and ice creams, among others. They have a great acceptance by the consumers due to its flavor and specific smell (Teixeira \& Novello, 2020). Besides, they present colors that range from yellow to dark orange (Yu et al., 2017; Rehman, Singh, \& Khurshid, 2018).

Also known as sweet lemon, Citrus limetta fruits are native to Asia and were originated from a natural cross with lemon Sicilian. It was occasionally discovered a tree that produced fruits less acid than other lemon trees, and from this stock plant the sweet lemon was reproduced by grafting. It is well grown in India, China, Southern Japan, Vietnam, Malaysia, Indonesia and Thailand (Khan, Mahmood, Siddiqui, \& Akhtar, 2016; Shakoor \& Nasar, 2016; Hashemi et al., 2017). 
According to Nicolosi's (2007) classification, the sweet lemon belongs to Citrus genus, limetta species, variety Risso, Subfamily Auranciaceas and Family Rutaceae. In Mexico these fruits are not so important when compared to other varieties of lemon and still have no commercial value, even they are produced in 14 counties. Besides, just like in Brazil, the availability of fruits from this species became lower due to the lack of marketing and introduction of new varieties (Colecio-Juárez et al., 2012).

The fruit characterization is very important to determine the genetic variability of a species that can support breeding programs, as well as its relationship with environmental factors (Nascimento, Cardoso, \& Cocozza, 2014). Genetic diversity is one of the features evaluated at the beginning of a breeding program. A lot of methods are available for that evaluation, differing in the ability to detect differences between genotypes, costs, use easement, consistency and repeatability of the results (Morales et al., 2011). Genetic diversity can be stated through agronomic, morphological and molecular features, among others (Amorim, Ramos, Ungaro, \& Kiihl, 2007).

Multivariate analysis techniques can be used to assay the divergence between accessions and select more important descriptors, in discrimination of accessions from a germplasm bank (Rodrigues, S. P. Carvalho, A. A. Carvalho, Carvalho Filho, \& Custódio, 2010). Among the techniques of statistics multivariate, the correlation analysis and clustering stand out (Cruz, Regazzi \& Carneiro, 2014). The knowledge of genetic diversity among accessions is very important to support breeding programs because it allows to characterize germplasm, control genetic erosion and registry new cultivars, and through that information breeding material can be selected (Youseif, El-Halwagi, Sayed \& El-Itriby, 2014).

Several studies highlighting the antioxidant activity in C. limetta juice were performed, as reported in Barreca, Bellocco, Caristi, Leuzzi, and Gattuso (2011), and Perez, Jiménez-Ferrer, Alonso, Botello-Amaro, and Zamilpa (2010) as well studies assessing the genetic evaluation of orange trees grafted onto lemon hybrid species aiming to obtain resistance to diseases (Pompeu Junior, Blumer, \& Resende, 2013). Youseif et al. (2014) evaluated the chemical properties and the genetic diversity of $C$. limetta juice through DNA extraction and Al-Anbari et al. (2014) evaluated the genetic diversity among $C$. limetta and others fifteen genotypes of citrus using RAPD markers. However, there are no studies aiming for the characterization of fruits from this species, and the evaluation of the genetic diversity is scarce and needs updated works that corroborates these studies. Therefore, the aim of this work was to characterize fruits from nine stock plants of $C$. limetta, as well as to evaluate genetic diversity between the fruits from the stock plants.

\section{Method}

\subsection{Area Description}

The fruits were grown in an orchard in Porto Nacional, Tocantins state, Brazil, located at $10^{\circ} 42^{\prime} \mathrm{S}$ and $48^{\circ} 25^{\prime} \mathrm{W}$, which according to Köppen's classification have climatic conditions of the Aw type, with tropical climate with season dry in the winter, the altitude is $422 \mathrm{~m}$ high and annual rainfall average is about 1500 and $1600 \mathrm{~mm}$.

\subsection{Material Collection}

The harvest occurred in September 2019 and the fruits were transported to Jataí, Goiás state, Brazil into polypropylene bags. At the laboratory located at $17^{\circ} 53^{\prime} \mathrm{S}$ and $52^{\circ} 43^{\prime} \mathrm{W}$, the fruits were washed, selected by the absence of injuries, and dried at room temperature.

\subsection{Fruit Description}

The fruits had the following characteristics: $325.6 \pm 82.6 \mathrm{~g}$ of weight, $84.5 \pm 8.9 \mathrm{~mm}$ of length, $87.2 \pm 8.4 \mathrm{~mm}$ of diameter and $92.6 \pm 10.4^{\circ}$ of hue angle, which means that the fruits were completely ripe, since as closer to $90^{\circ}$ more intense is the color yellow of the sample (Konica Minolta, 2015).

\subsection{Experimental Design}

The experimental design was completely randomized with nine treatments and five replicates. The treatments consisted of one stock plant, in which five fruits were harvested from each one.

\subsection{Features Evaluated}

The five fruits from each stock plant were evaluated for weight, length, diameter, peel and pulp color, juice yield, and soluble solids content.

\subsubsection{Weight}

The weight was evaluated with a weighing machine, in which the fruits were weighed individually and the results were given in $\mathrm{g}$. 


\subsubsection{Length}

The length was obtained by measurement across the transversal section with the aid of a caliper and the results were expressed in $\mathrm{mm}$.

\subsubsection{Diameter}

The diameter was obtained by measurement across the longitudinal section of the fruits with the aid of a caliper and the results were expressed in $\mathrm{mm}$.

\subsubsection{Peel and Pulp Color}

The peel and pulp color were determined with two measurements on opposite sides of the fruit peel and one internal measurement in the middle section of the pulp. The measure was performed on a colorimeter Konica Minolta using CIELab color space. On CIELab pattern the coordinate L* represents the luminosity degree of the sample (The values range from 0 to 100 , which $\mathrm{L}=0$ is totally black and $\mathrm{L}=100$ is totally white), the coordinate $a^{*}$ express the variation between red and green (The values range from 0 to 60 , which negative values represent the color green and positive represents the color red), the coordinate $b^{*}$ represents the variation degree between yellow and blue (Also ranging from 0 to 60 , with blue being expressed by negative values and yellow represented by positive one), the chromaticity is expressed by $\mathrm{C}^{*}$ and the color is expressed by hue angle $\left(\mathrm{h}^{\circ}\right)$ (Konica Minolta, 2015).

\subsubsection{Juice Yield}

The juice yield was obtained by the quotient between the weight of fruit and juice. After the pulp extraction, both were weighed in the weighing machine and the results were expressed in percentage (\%).

\subsubsection{Soluble Solids Content}

The soluble solids content was determined on a digital refractometer, which a few drops of juice were placed in the refractometer reader and the results were given in ${ }^{\circ}$ Brix as recommended by the Association of Official Analytical Chemistry [AOAC] (2016).

\subsection{Data Analysis}

The data were subjected to normality and homogeneity test and to $\mathrm{F}$ test from analysis of variance. The averages were compared on Tukey's test, assuming $5 \%$ of error probability $(\mathrm{P} \leq 0.05)$. The measure of similarity and clustering of the stock plants were obtained by Tocher's optimization algorithm and by unweighted paired group method with arithmetic means (UPGMA) dendrogram; and through Singh's (1981) method, the relative contribution of the fifteen features was established. through the nine collect environment, the mean Euclidian distance was estimated based on the features evaluated. Aiming to check the consistency of the clustering, the cophenetic correlation coefficient (CCC) between the genetic dissimilarity matrix and the cophenetic values matrix was calculated. Statistical analysis was performed on software Rbio version 119: 06/06/2019 (Bhering, 2017) and Genes (Cruz, 2013).

\section{Results}

There was no difference in the averages of weight, length, and diameter between the nine stock plants. It can be observed that the fruits had weight ranging from 240 to $370 \mathrm{~g}$, the length ranging from 76 to $90 \mathrm{~mm}$, and the diameter ranging from 77 to $93 \mathrm{~mm}$ (Table 1). 
Table 1. Fruit weight (FW) [g], fruit length (FL) [mm], fruit diameter (FD) [mm], color parameter: luminosity $(\mathrm{L})$, coordinate $\mathrm{a}^{*}(\mathrm{a})$, coordinate $\mathrm{b}^{*}(\mathrm{~b})$, chroma $(\mathrm{C})$ and hue angle $\left(\mathrm{h}^{\circ}\right)$ of the peel on Citrus limetta fruits from nine stock plants (SP)

\begin{tabular}{lllllllll}
\hline SP & FW & FL & FD & L & a & b & C & $\mathrm{h}^{\circ}$ \\
\hline 1 & 338.50 & 86.90 & 92.28 & $44.46 \mathrm{~b}$ & -2.44 & $13.30 \mathrm{~b}$ & $19.84 \mathrm{~b}$ & 107.24 \\
2 & 350.32 & 88.50 & 89.19 & $42.96 \mathrm{~b}$ & -1.52 & $9.22 \mathrm{~b}$ & $9.46 \mathrm{~b}$ & 96.88 \\
3 & 343.05 & 85.92 & 89.29 & $49.78 \mathrm{~b}$ & -0.80 & $17.70 \mathrm{~b}$ & $19.66 \mathrm{~b}$ & 91.22 \\
4 & 368.79 & 89.96 & 91.07 & $70.12 \mathrm{a}$ & -0.04 & $40.96 \mathrm{a}$ & $41.08 \mathrm{a}$ & 90.20 \\
5 & 305.84 & 82.49 & 86.29 & $65.24 \mathrm{a}$ & 0.56 & $38.60 \mathrm{a}$ & $37.82 \mathrm{a}$ & 89.44 \\
6 & 354.92 & 88.49 & 88.54 & $64.68 \mathrm{a}$ & -0.88 & $37.00 \mathrm{a}$ & $37.00 \mathrm{a}$ & 90.90 \\
7 & 356.77 & 84.35 & 88.82 & $64.48 \mathrm{a}$ & 1.94 & $39.72 \mathrm{a}$ & $39.92 \mathrm{a}$ & 87.42 \\
8 & 263.14 & 76.90 & 77.62 & $65.84 \mathrm{a}$ & 0.82 & $39.38 \mathrm{a}$ & $39.46 \mathrm{a}$ & 89.20 \\
9 & 243.75 & 76.93 & 80.86 & $67.28 \mathrm{a}$ & 0.02 & $39.86 \mathrm{a}$ & $39.96 \mathrm{a}$ & 90.38 \\
$\mathrm{~F}$ & $1.36^{\text {ns }}$ & $1.66^{\text {ns }}$ & 1.95 & 19.95 & $1.05^{\text {ns }}$ & 20.18 & 17.96 & $2.16^{\text {ns }}$ \\
\hline
\end{tabular}

Note. Averages followed by ns in the column are not different at $5 \%$ level by Tukey's test.

The fruits from the stock plants $4,5,6,7,8$, and 9 showed higher luminosity, differing from the other stock plants. Although there are no significant contrasts between the averages from the stock plants, the fruits from stock plants 1 and 2 had averages of a* from peel more negative, which indicates that those fruits were greener. The fruits presented positive values for coordinate $b^{*}$, which means the predominance of yellow in the peel of the fruits, and the stock plants 4, 5, 6, 7, 8 and 9 differed from the others stock plants, which was expected since the fruits from stock plants 1 and 2 had more predominance of green $\left(a^{*}\right)$ (Table 1$)$.

The chroma of the peel in fruits of stock plants $4,5,6,7,8$, and 9 differed from the other stock plants, indicating that these fruits have a more intense color. There is no difference between the hue angle of the peel of fruits from the stock plants evaluated, which indicates that even if there is a difference in coordinate $\mathrm{a}^{*}$ and $\mathrm{b}^{*}$, the color of the peel of the fruits in the stock plants were closely from each other, remaining in the same quadrant (Table 1).

There was a difference from the luminosity of the pulp between the stock plants, and the highest values were observed in stock plants $5,7,8$, and 9 , indicating that the pulp was brighter than the others, especially stock plants 1 and 2 (Table 2).

Table 2. Averages of color parameter: luminosity (L), coordinate $a^{*}(a)$, coordinate $b^{*}(b)$, chroma (C), hue angle $\left(\mathrm{h}^{\circ}\right)$, juice yield $(\mathrm{JY})[\%]$ and soluble solids content (SS) [ ${ }^{\circ}$ Brix] of Citrus limetta pulp from nine stock plants (SP)

\begin{tabular}{llllllll}
\hline $\mathrm{SP}$ & $\mathrm{L}$ & $\mathrm{a}$ & $\mathrm{b}$ & $\mathrm{C}$ & $\mathrm{h}^{\circ}$ & JY & SS \\
\hline 1 & $39.66 \mathrm{c}$ & $-2.34 \mathrm{a}$ & $4.12 \mathrm{c}$ & $4.78 \mathrm{c}$ & $121.00 \mathrm{a}$ & 51.20 & 8.56 \\
2 & $44.56 \mathrm{bc}$ & $-2.52 \mathrm{ab}$ & $6.78 \mathrm{~b}$ & $7.22 \mathrm{bc}$ & $109.98 \mathrm{~b}$ & 74.00 & 8.54 \\
3 & $48.5 \mathrm{ab}$ & $-3.28 \mathrm{ab}$ & $8.60 \mathrm{ab}$ & $9.24 \mathrm{ab}$ & $111.08 \mathrm{~b}$ & 66.80 & 8.50 \\
4 & $47.84 \mathrm{ab}$ & $-3.20 \mathrm{ab}$ & $8.42 \mathrm{ab}$ & $9.02 \mathrm{ab}$ & $110.66 \mathrm{~b}$ & 73.60 & 9.12 \\
5 & $50.06 \mathrm{a}$ & $-3.60 \mathrm{ab}$ & $8.96 \mathrm{ab}$ & $9.52 \mathrm{ab}$ & $111.88 \mathrm{~b}$ & 64.60 & 8.68 \\
6 & $48.1 \mathrm{ab}$ & $-3.82 \mathrm{ab}$ & $8.74 \mathrm{ab}$ & $9.54 \mathrm{ab}$ & $113.62 \mathrm{ab}$ & 66.80 & 9.48 \\
7 & $50.68 \mathrm{a}$ & $-3.30 \mathrm{ab}$ & $8.92 \mathrm{ab}$ & $9.62 \mathrm{ab}$ & $109.98 \mathrm{~b}$ & 72.20 & 8.68 \\
8 & $50.82 \mathrm{a}$ & $-3.98 \mathrm{~b}$ & $9.00 \mathrm{ab}$ & $9.82 \mathrm{ab}$ & $113.82 \mathrm{ab}$ & 61.00 & 9.72 \\
9 & $50.96 \mathrm{a}$ & $-3.42 \mathrm{ab}$ & $10.22 \mathrm{a}$ & $10.80 \mathrm{a}$ & $108.38 \mathrm{~b}$ & 54.60 & 9.58 \\
$\mathrm{~F}$ & 11.51 & 2.41 & 10.50 & 9.98 & 3.86 & $0.78^{\text {ns }}$ & $1.99^{\text {ns }}$ \\
\hline
\end{tabular}

Note. Averages followed by ns in the column are not different at $5 \%$ level by Tukey's test.

The coordinate $a^{*}$ of the pulp from the fruits of nine stock plants presented negative values, indicating the predominance of the color green. There was a difference between the stock plants evaluated, which the fruits from stock plant 1 had lighter green pulp and stock plant 8 has darker green pulp (Table 2).

There was a significant contrast between the averages of the stock plants evaluated for coordinate $b^{*}$ and chroma (C). All fruits had a predominance of the color yellow, which is evidenced by the positive averages of $b$. The stock plant 1 produced fruits with pulp less yellow and the fruits from stock plant 9 were more yellow. Similarly, 
the highest intensity of the pulp color was observed in fruits from stock plant 9 and the lower was observed in fruits from stock plant 1, which is expressed by C (Table 2).

The hue angle of the pulp differed between the stock plants. Even all evaluated fruits presented color above $100^{\circ}$, the fruits from stock plant 1 stood out with $121^{\circ}$, indicating that the fruits have a strong orange color (Table 2).

The stock plants did not present significant contrast for juice yield and soluble solids content, the average value for soluble solids was $8.98^{\circ}$ Brix (Table 2).

There were observed high values of coefficient of variation for color coordinates, especially for fruits peel as like for fruit weight, which indicates high genetic diversity for this parameter (Table 3).

Table 3. Average, minimum, maximum, coefficient of variation (CV) and relative importance (S.j) from 15 variables to dissimilarity from 9 stock plants of Citrus limetta

\begin{tabular}{llllll}
\hline Variable & Average & Minimum & Maximum & CV $(\%)$ & S.j $(\%)$ \\
\hline FW & 325.56 & 202.37 & 524.76 & 25.47 & 75.31 \\
FL & 84.49 & 70.24 & 102.77 & 9.95 & 0.95 \\
FD & 87.10 & 70.74 & 103.86 & 8.85 & 0.93 \\
$\mathrm{LPe}$ & 59.42 & 37.70 & 76.50 & 8.90 & 4.49 \\
$\mathrm{aPe}$ & -0.26 & -4.70 & 8.10 & 18.32 & 0.06 \\
$\mathrm{bPe}$ & 30.63 & 1.90 & 45.20 & 19.85 & 6.94 \\
$\mathrm{CPe}$ & 31.57 & 5.30 & 45.40 & 19.85 & 5.68 \\
$\mathrm{hPe}$ & 92.60 & 72.50 & 144.10 & 10.28 & 1.58 \\
$\mathrm{LP}$ & 47.90 & 37.90 & 54.40 & 5.09 & 0.55 \\
$\mathrm{aP}$ & -3.27 & -5.50 & -1.7 & 23.95 & 0.01 \\
$\mathrm{bP}$ & 8.19 & 3.30 & 11.60 & 14.87 & 0.12 \\
$\mathrm{CP}$ & 8.84 & 4.20 & 12.60 & 14.34 & 0.13 \\
$\mathrm{hP}$ & 112.30 & 101.30 & 128.40 & 3.73 & 0.54 \\
JY & 64.97 & 21.00 & 128.00 & 31.55 & 2.65 \\
$\mathrm{SS}$ & 8.98 & 7.40 & 12.40 & 8.71 & 0.009 \\
\hline
\end{tabular}

Note. FW: Fruit weight (g), FL: fruit length (mm), FD: fruit diameter (mm), LPe: coordinate L of peel, aPe: coordinate a of peel, bPe: coordinate b of peel, CPe: coordinate $\mathrm{C}$ of peel, hPe: coordinate $\mathrm{h}^{\circ}$ of peel, LP: coordinate L of pulp, aP: coordinate a of pulp, bP: coordinate $\mathrm{b}$ of pulp, CP: coordinate $\mathrm{C}$ of pulp, hP: coordinate $\mathrm{h}^{\circ}$ of pulp, JY: juice yield (\%), SS: soluble solids content ( ${ }^{\circ}$ Brix).

The relative importance of characters for the genetic dissimilarity between the accessions using the criterion proposed by Singh (1981), had a high range in data distribution, ranging from 0.01 to $75.31 \%$. The features who contributed most for total variation (or genetic dissimilarity) were fruit weight $(75.31 \%)$, coordinate $\mathrm{b}$ of peel (6.94\%), and coordinate $\mathrm{C}$ of peel (5.68\%) (Table 3).

The clustering by Tocher's method, using as dissimilarity measurement the mean Euclidian distance from the 15 features, promoted the formation of three groups (Table 4), in which can be observed that the stock plants 5, 7, 4, 6 , and 3 were the most similar and the most similar were the stock plants 1 and 2 .

Table 4. Groups established by Tocher's method, based on 15 features evaluated in 9 stock plants of Citrus limetta

\begin{tabular}{ll}
\hline Groups & Stock Plants \\
\hline 1 & 57463 \\
2 & 89 \\
3 & 12 \\
\hline
\end{tabular}

The group 1 was formed by five stock plants, and group 2 and 3 were formed by two stock plants according to Tocher's method (Table 4).

Through UPGMA clustering method, the stock plants were clustered in three groups, based on the cutoff point of $13.85 \%$ of distance using Mojena's (1977) criteria, and the dendrogram was obtained from the dissimilarity 
matrix created by mean Euclidian distance, based on 15 features from 9 stock plants (Figure 1). The cophenetic correlation coefficient was 0.77 .

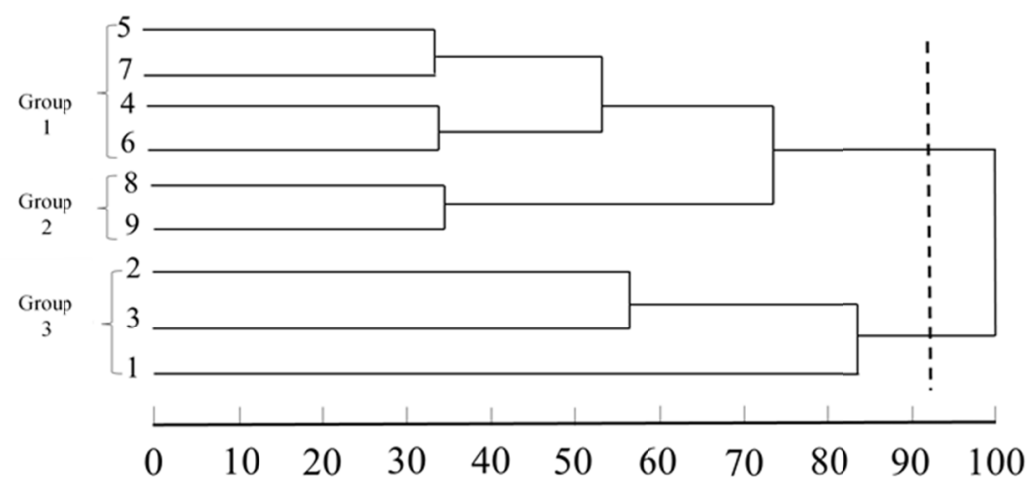

Figure 1. Dendrogram created by unweighted paired group method with arithmetic means (UPGMA) from the dissimilarity between fruits through mean Euclidean distance from 9 stock plants of Citrus limetta

Stock plants 4, 5, 6, and 7 were clustered in group 1 and were the most similar, stock plants 8 and 9 in group 2 , and stock plants 1,2, and 3 in group 3 and were the most dissimilar, which indicates the high variability between the fruits from the 9 stock plants evaluated (Figure 1).

\section{Discussion}

Fruit weight can be an important feature for industrialization and as a selection parameter for breeding. Machado, Siqueira, Salomão, Cecon, and Silva (2017), working with sour lime "Tahiti” grafted onto "Cleopatra" in Janaíba, Minas Gerais, Brazil, produced fruits with an average of $82.12 \mathrm{~g}$. Regarding the values founded on the present work of $325.6 \mathrm{~g}$, the increase must be due to the use of different varieties and climate conditions. According to Phate, Malmathanraj, and Palanisamy (2019), the criteria for the classification of sweet lemon based on weight range from $A$ to $D$, which A comprehends the fruits heavier than $200 \mathrm{~g}$ and $\mathrm{D}$ the fruits lighter than $100 \mathrm{~g}$.

Machado et al. (2017), in the same work with sour lime "Tahiti" who took place in four years, also did not observe differences in the diameter of the fruits among the evaluated years. It is known that the harvest point of sour lime "Tahiti" is when the fruits reach $47 \mathrm{~mm}$ of diameter. On the present work, C. limetta fruits had averages of $84.5 \mathrm{~mm}$ in diameter. However, there are no specific studies for this species establishing what would be the ideal size for harvest.

The fruit length and color are important features for the classification of citrus (Khojastehnazhand, Omid, \& Tabatabaeefar, 2010). Also, the size and weight of fruits is a very important feature for fresh fruits in the processing industry, because it has an influence on several factors including the drying time, which implies in production costs (Viana, Reis, Sena, Santos Júnior, \& Silva, 2017). Phate et al. (2019), evaluating the size and weight of sweet lemon fruits to be used as a conversion factor for validating models in the computer vision system, obtained fruits with $62 \mathrm{~mm}$ of length and $134 \mathrm{~g}$, lower than the values from the present work. Despite the sweet lemon is not commercially exploited, their fruits present great potential for the industry due to its characteristics.

The coordinate $\mathrm{L}$ measures the intensity of brightness who can range from 0 to 100 , being that closer to 0 darker is the sample, and closer to 100 brighter is the surface (Konica Minolta, 2015), thus, the stock plants 4, 5, 6, 7, 8 and 9 presented the brightest peel. The hue angle $\left(\mathrm{h}^{\circ}\right)$ is the angle between the hypotenuse and 0 degrees in the $a^{*}$ axis. Durigan, Mattiuz, and Durigan (2005), evaluated fruits of sour lime "Tahiti" (C. latifolia) that present brightness of 54.08 and hue angle of $127.25^{\circ}$. Pereira, Machado, and Costa (2014), reported that fruits of orange 'valência delta' ( $C$. sinensis) stored presented brightness higher than 50 and increased along the time of storage, which indicates that the fruits were becoming clear, and the hue angle was closer to $90^{\circ}$, similar to the results obtained in the present work.

The values of $\mathrm{L}$ and $\mathrm{h}^{\circ}$ from fruits of sweet lemon evaluated in this paper indicates that the fruits were fully ripe with pulp and peel with light yellow color. The color is strongly influenced by environmental factors and it is one of the main factors that influence the consumption and marketing of the fruits since the consumers rather 
fruits with a uniform color of peel because they associate it with sweeter and ripe fruits (Medina, Rena, Siqueira, \& Machado, 2005; Malgarim, Cantillano, Oliveira, \& Treptow, 2008; Oliveira, Brunini, \& Nunes, 2014). It is possible that high temperatures increase the respiratory rate and anticipates ripening (Drehmer \& Amarante, 2008).

According to the Brazilian Institute for Quality in Agriculture [HORTIBRASIL] (2000), the minimum value of juice yield for lemon is $40 \%$, which means that $C$. limetta fruits meet this demand. Despite being different species, sour lime "Tahiti" on the work proposed by Machado et al. (2017), presented 48\% of juice yield, lower than those found in this paper. Chaves Neto, Silva, and Santos, (2018), obtained a juice yield of $69.45 \pm 1.03 \%$ for "Galego" lemon (C. aurantifolia). Ferreira, Bastianel, Azevedo, and Negri, (2018) evaluating fourteen genotypes of Citrus lemon grafted onto "Rangpur" lime in São Paulo, Brazil, obtained juice yield ranging from 37 to $59 \%$, being the genotype "Meyer" the greater.

Soluble solids can indicate the amount of sugars in fruit pulp, being that the sweet flavor is related to acidity in fruits. Higher temperatures and lower thermic range can also increase the accumulation of soluble solids content (Santos et al., 2010). Malgarim et al. (2008), evaluated fruits of the citrus hybrid cultivar 'Nova' (Citrus clementina $\times(C$. paradisi $\times C$. tangerina $))$ with $12{ }^{\circ}$ Brix of soluble solids content. Oliveira et al. (2014), obtained soluble solids content of $10.04{ }^{\circ}$ Brix on mandarin fruits marketed in Ribeirão Preto, São Paulo, Brazil, and Goes et al. (2012), obtained $10.90^{\circ}$ Brix in sour lime "Tahiti” grown in Ceará, Brazil.

The coefficient of variation for breeding is very important because allow the researcher to select features according to fruit destination, if for fresh consumption or to industry. The relative importance can contribute to the variables discard, allowing a better choice of the features considered in a genetic diversity assay (Cruz et al., 2014). Kopp et al. (2007), evaluating ten rice genotypes aiming to improve the cophenetic correlation coefficient obtained values of 0.72 , and these authors report that some genotypes can negatively influence the representativeness of the stock plant by its grouping and that the elimination of these genotypes result in an increase in the cophenetic correlation coefficient, which increases the representativeness of the genetic distance.

The UPGMA method allows reunite the biggest number of subjects on first groups and usually isolated subjects on the last groups. In that kind of assay, UPGMA is interesting because it identifies subjects genetically nonsimilar and not only groups (Galate, Mota, Gaia, \& Costa, 2014). This technique increases the information circa the difference between the stock plants, which in this study are the stock plants 1 and 2 who composes the group 3, stock plants 8 and 9 in group 2, and the major number of stock plants (six) on group 1.

To occur the evolution of species the genetic diversity is vital for natural selection and is populations with genetic variability who occurs the selection of plants with traits of agricultural interests such as fruits with attractive flavor and resistance to pests and diseases (Wagner Júnior, Bruckner, Cantín, Sánchez, \& Cruz, 2011). According to Carpentieri-Pípolo et al. (2000), the use of parent genotypes with the highest divergence as possible is important to maximize the heterogeneity of hybrids, increase the probability of occurrence of superior segregating in advanced generations and increase genetic basis.

\section{Conclusions}

There is genetic diversity between the accessions evaluated, and the methodology was efficient to show this diversity.

The nine stock plants evaluated presented genetic diversity regarding fruit characteristics thorough Tocher's method.

The stock plants who presented more similarities are 5,7,4,6, and 1,3,2, while 8 and 9 are the most distant according to UPGMA method.

The nine stock plants presented similar physical characteristics, especially for size, weight, juice yield, and soluble solids content.

\section{Acknowledgements}

The authors thank the Coordination for the Improvement of Higher Education Personnel (CAPES) and the National Council for Scientific and Technological Development (CNPq) for financial support.

\section{References}

AL-Anbari, A. K., Kanawapee, N., AL-Kazragi, T. A., Al-Jewari, H., Al-Mashhadani, A., Barusrux, S., ... Theerakulpisut, P. (2014). Genetic diversity of citrus (Rutaceae) in Iraq based on random amplified polymorphic DNA (RAPD) markers. African Journal of Agricultural Research, 9(11), 1012-1019. https://doi.org/10.5897/AJAR2013.8306 
Amorim, E. P., Ramos, N. P., Ungaro, M. R. G., \& Kiih, T. A. M. (2007). Divergência genética em genótipos de girassol. Ciencia E Agrotecnologia, 31(6), 1637-1644. https://doi.org/10.1590/S1413-70542007000600006

AOAC (Association of Official Analytical Chemists). (2016). Official methods of analysis.

Barreca, A. D. Bellocco, E., Caristi, C., Leuzzi, U., \& Gattuso, G. (2011). Flavonoid profile and radical-scavenging activity of Mediterranean sweet lemon (Citrus limetta Risso) juice. Food Chemistry, 129(2), 417-422. https://doi.org/10.1016/j.foodchem.2011.04.093

Bhering, L. L. (2017). Rbio: A tool for biometric and statistical analysis using the R platform. Crop Breeding and Applied Biotechnology, 17(2), 187-190. https://doi.org/10.1590/1984-70332017V17N2S29

ABECITRUS (Brazilian Association of Citrus Exporters). (2020). Exportações de FCOJ-Safra Atual. Retrieved from http://www.abecitrus.com.br

HORTIBRASIL (Brazilian Institute for Quality in Agriculture). (2000). Programa brasileiro para melhoria dos padrões comerciais e embalagens de hortigranjeiros: classificação do limão (lima ácida) Tahiti (Citrus latifolia Tanaka) (p. 5). São Paulo: CEAGESP.

Carpentieri-Pípolo, V., Destro, D., Prete, C. E. C., Gonzales, M. G. N., Popper, I., Zanatta, S., \& Silva, A. M. D. (2000). Seleção de genótipos parentais de acerola com base na divergência genética multivariada. Pesquisa Agropecuaria Brasileira, 35(8), 1613-1619. https://doi.org/10.1590/S0100-204X2000000800014

Chaves Neto, J. R., Silva, S. de M., \& Santos, L. F. (2018). Caracterização e qualidade de frutos de limão 'galego'. Colloquium Agrariae, 14(4), 10-19. https://doi.org/10.5747/CA.2018.V14.N4.A244

Colecio-Juárez, M. C., Rubio-Núnez, R. E., Botello-Álvarez, J. E., Martinez-González, G. M., Navarrete-Bolanos, J. L., \& Jiménez-Islas, H. (2012). Characterization of Volatile Compounds in the Essential Oil of Sweet Lime (Citrus limetta Risso). Chilean Journal of Agricultural Research, 72(2), 276-280. https://doi.org/10.4067/S0718-58392012000200017

Cruz, C. D. (2013). Genes: A software package for analysis in experimental statistics and quantitative genetics. Acta Scientiarum. Agronomy, 35(3), 271-276. https://doi.org/10.4025/actasciagron.v35i3.21251

Cruz, C. D., Carneiro, P. C. S., \& Regazzi, A. J. (2014). Modelos biométricos aplicados ao melhoramento genético (p. 2). Viçosa: Ed. da UFV.

Drehmer, A. M. F., \& Amarante, C. V. T. (2008). Conservação pós-colheita de frutos de araçá-vermelho em função do estádio de maturação e temperatura de armazenamento. Revista Brasileira de Fruticultura, 30(2), 322-326. https://doi.org/10.1590/S0100-29452008000200009

Durigan, M. F. B., Mattiuz, B. H., \& Durigan, J. F. (2005). Injúrias mecânicas na qualidade pós-colheita de lima ácida "Tahiti” armazenada sob condição ambiente. Revista Brasileira de Fruticultura, 27(3), $369-372$. https://doi.org/10.1590/S0100-29452005000300008

Eryildiz, B., Lukitawesa, L., \& Taherzadeh, M. J. (2020). Effect of pH, Substrate Loading, oxygen, and Methanogens Inhibitors on Volatile Fatty Acid (VFA) Production from Citrus Waste by Anaerobic Digestion. Bioresource Technology, 302, 122800. https://doi.org/10.1016/J.BIORTECH.2020.122800

Ferreira, R. V., Bastianel, M., Azevedo, F. A., \& Negri, J. D. D. (2018). Desenvolvimento vegetativo e características físico-químicas dos frutos de quatorze genótipos de limão. Citrus Research \& Technology, 39. https://doi.org/10.4322/crt.14818

Galate, R. S., Mota, M. G. C., Gaia, J. M. D., \& Costa, M. D. S. S. (2014). Distância fenotípica entre matrizes de açaizeiro (Euterpe oleracea Mart.) procedentes do nordeste do Pará. Semina: Ciências Agrárias, 35(4), 1667-1681. https://doi.org/10.5433/1679-0359.2014v35n4p1667

Goes, T. S., Carmo, J. S., Braga, T. R., Maria, M., Oliveira, T., Silva, L. R., \& Vasconcelos Torres, L. B. (2012). Caracterização física e físico-química de frutos do limão "Tahiti" (Citrus latifolia T.) cultivados em Guaraciaba do Norte-CE. Cultivando o Saber, 5(3), 14-21.

Hashemi, S. M. B., Khaneghah, A. M., Barba, F. J., Nemati, Z., Shokofti, S. S., \& Alizadeh, F. (2017). Fermented sweet lemon juice (Citrus limetta) using Lactobacillus plantarum LS5: Chemical composition, antioxidant and antibacterial activities. Journal of Functional Foods, 38, 409-414. https://doi.org/10.1016/ J.JFF.2017.09.040

Khan, A. A., Mahmood, T., Siddiqui, H. H., \& Akhtar, J. (2016). Phytochemical and pharmacological properties on Citrus limetta (Mosambi). Journal of Chemical and Pharmaceutical Research, 8(3), 555-563. 
Khojastehnazhand, M., Omid, M., \& Tabatabaeefar, A. (2010). Development of a lemon sorting system based on color and size. African Journal of Plant Science, 4(4), 122-127.

Konica Minolta. (2015). Compreendendo o Espaço de Cor CIE $L^{*} C^{*} h$. Retrieved from http://sensing.konica minolta.com.br/2015/08/compreendendo-o-espaco-de-cor-cie-lch.

Kopp, M. M., Souza, V. Q., Coimbra, J. L. M., Luz, V. K., Marini, N., \& Oliveira, A. C. (2007). Melhoria da correlação cofenética pela exclusão de unidades experimentais na construção de dendrogramas. Revista Da FZVA, 14(2).

Machado, D. L. M., Siqueira, D. L. D., Salomão, L. C. C., Cecon, P. R., \& Silva, D. F. P. (2017). Evaluation of rootstocks for 'Tahiti' acid lime in northern state of minas gerais. Revista Brasileira de Fruticultura, 39(1), 1-12. https://doi.org/10.1590/0100-29452017790

Malgarim, M., Cantilano, R., Oliveira, R., \& Treptow, R. (2008). Qualidade pós-colheita de citros 'Nova' em diferentes períodos de armazenamento e comercialização. Revista Brasileira Agrociência, 14(1), 19-23.

Matias, R. G. P., Ribeiro, M. R., Silva, D. F. P., Silva, J. O. C., Oliveira, S. P., \& Bruckner, C. H. (2014). Características físicas e químicas de pêssego em função da altura de inserção na planta. Comunicata Scientiae, 5(4), 435-440. https://doi.org/10.14295/CS.V5I4.409

Medina, C. L., Rena, A. B., Siqueira, D. L., \& Machado, E. C. (2005). In D. Mattos Júnior, J. D. de Negri, \& R. M. Pio (Eds.), Fisiologia dos citros (pp. 147-195).

Mojena, R. (1977). Hierarchical grouping methods and stopping rules: An evaluation. The Computer Journal, 20(4), 359-363. https://doi.org/10.1093/COMJNL/20.4.359

Morales, R. G. F., Resende, J. T. V., Faria, M. V., Silva, P. R., Figueiredo, A. S. T., \& Carminatti, R. (2011). Divergência genética em cultivares de morangueiro, baseada em caracteres morfoagronômicos. Revista Ceres, 58(3), 323-329. https://doi.org/10.1590/S0034-737X2011000300012

Nascimento, R. S. M., Cardoso, J. A., \& Cocozza, F. D. M. (2014). Caracterização física e físico-química de frutos de mangabeira (Hancornia speciosa Gomes) no oeste da Bahia. Revista Brasileira de Engenharia Agricola e Ambiental, 18(8), 856-860. https://doi.org/10.1590/1807-1929/AGRIAMBI.V18N08P856-860

Nicolosi, E. (2007). Origin and taxonomy. Citrus Genetics, Breeding and Biotechnology, 19-43. https://doi.org/ $10.1079 / 9780851990194.0000$

Oliveira, C. A., Brunini, M. A., \& Nunes, G. S. (2014). Qualidade da tangerina 'ponkan' comercializada na ceagesp-entreposto de ribeirão Preto-SP. Nucleus, 11(2), 307-316. https://doi.org/10.3738/1982.2278.1373

Pereira, G. S., Machado, F. L. C, \& Costa, J. M. C. (2014). Aplicação de recobrimento prolonga a qualidade pós-colheita de laranja 'Valência Delta' durante armazenamento ambiente. Revista Ciência Agronômica, 45(3), 520-527. https://doi.org/10.1590/S1806-66902014000300012

Perez, Y. Y., Jimenez-Ferrer, E., Alonso, D., Botello-Amaro, C. A., \& Zamilpa, A. (2010). Citrus limetta leaves extract antagonizes the hypertensive effect of angiotensin II. Journal of Ethnopharmacology, 128(3), 611-614. https://doi.org/10.1016/J.JEP.2010.01.059

Phate, V. R., Malmathanraj, R., \& Palanisamy, P. (2019). Classification and weighing of sweet lime (Citrus limetta) for packaging using computer vision system. Journal of Food Measurement and Characterization, 13(2), 1451-1468. https://doi.org/10.1007/S11694-019-00061-3

Pompeu Junior, J., Blumer, S., \& Resende, M. D. V. (2013). Avaliação genética de seleções e híbridos de limões cravo, volkameriano e rugoso como porta-enxertos para laranjeiras Valência na presença da morte súbita dos citros. Revista Brasileira de Fruticultura, 35(1), 199-209. https://doi.org/10.1590/S0100-2945201300 0100023

Rehman, M., Singh, Z., \& Khurshid, T. (2018). Pre-harvest spray application of abscisic acid (S-ABA) regulates fruit colour development and quality in early maturing M7 Navel orange. Scientia Horticulturae, 229(1), 1-9. https://doi.org/10.1016/J.SCIENTA.2017.10.012

Rodrigues, H. C. A., Carvalho, S. P., Carvalho, A. A., Filho, J. L. S. C., \& Custódio, T. N. (2010). Avaliação da diversidade genética entre acessos de mamoneira (Ricinus communis L.) por meio de caracteres morfoagronômicos. Revista Ceres, 57(6), 773-777. https://doi.org/10.1590/S0034-737X2010000600012 
Santos, D., Matarazzo, P. H. M., Silva, D. F. P., Siqueira, D. L., Santos, D. C. M., \& Lucena, C. C. (2010). Caracterização físico-química de frutos cítricos apirênicos produzidos em Viçosa, Minas Gerais. Revista Ceres, 57(3), 393-400. https://doi.org/10.1590/S0034-737X2010000300016

Sarker, N. I., Barman, S. C., Islam, M. M., Islam, M. R., \& Chakma, A. S. (2017). Role of lemon (Citrus limon) production on livelihoods of rural people in Bangladesh. Journal of Agricultural Economics and Rural Development, 2(1), 053-063.

Shakoor, S., \& Nasar, A. (2016). Removal of methylene blue dye from artificially contaminated water using citrus limetta peel waste as a very low-cost adsorbent. Journal of the Taiwan Institute of Chemical Engineers, 66, 154-163. https://doi.org/10.1016/J.JTICE.2016.06.009

Silva, R. A., Agra, A. C., Aleixo, D. L., Nóbrega, V. R., \& Dantas, E. A. (2011). Situação econômica e produtiva da cultura dos citros no estado da paraíba. Revista Verde de Agroecologia e Desenvolvimento Sustentável, 6(3), 39-48. https://doi.org/10.18378/RVADS.V6I3.740

Singh, G. (1981). Late Quaternary pollen records and seasonal palaeoclimates of Lake Frome, South Australia. Hydrobiologia, 81(1), 419-430. https://doi.org/10.1007/978-94-009-8665-7_29

Teixeira, F., \& Novello, D. (2020). Physico-chemical, nutritional and sensory aspects of the addition of Citrus fruit by-products in gelation products: A systematic review. Research, Society and Development, 9(3), 180932669. https://doi.org/10.33448/RSD-V9I3.2669

Viana, E. D. S., Reis, R. C., Sena, L. D. O., Júnior, M. B. D. S., \& Silva, P. N. R. D. (2017). Produção de bananas-passa com frutos de variedades melhoradas e avaliação da qualidade físico-química e sensorial. Boletim do Centro de Pesquisa de Processamento de Alimentos, 35(1). https://doi.org/10.5380/cep.v35i1. 55944

Wagner Júnior, A., Bruckner, C. H., Cantín, C. M., Sánchez, M. A. M., \& Cruz, C. D. (2011). Divergência genética entre progênies de pessegueiro em Zaragoza, Espanha. Revista Brasileira de Fruticultura, 33(1), 303-310. https://doi.org/10.1590/S0100-29452011005000045

Youseif, S. H., El-Halwagi, A., Sayed, H. A., \& El-Itribi, H. A. (2014). Chemical analyses, antibacterial activity and genetic diversity assessment of some Egyptian Citrus spp. cultivars. African Journal of Biotechnology, 13(26), 2626-2636. https://doi.org/10.5897/AJB2014.13772

Yu, Y., Bai, J., Chen, C., Plotto, A., Yu, Q., Baldwin, E.A., \& Gmitter, F.G. (2017). Identification of QTLs controlling aroma volatiles using a 'Fortune' $\times$ 'Murcott' (Citrus reticulata) population. BMC Genomics, 1(1), 646-660. https://doi.org/10.1186/s12864-017-4043-5

\section{Copyrights}

Copyright for this article is retained by the author(s), with first publication rights granted to the journal.

This is an open-access article distributed under the terms and conditions of the Creative Commons Attribution license (http://creativecommons.org/licenses/by/4.0/). 